\title{
Groundwater Hydrochemical Characteristics in a Plain River Network Region: Effects of Dissolved Organic Carbon and Possible Traceability of Pollution Sources
}

\section{Ning Ma}

Northwest A\&F University: Northwest Agriculture and Forestry University

\section{Li Gao}

Institute for sustainable industries and liveable cities, victoria university

\section{Zhengkui Ge}

Northwest A\&F University: Northwest Agriculture and Forestry University

En Hu

Shaanxi Provincial Academy of Environmental Science

\section{Baozhu Pan}

State Key Laboratory of Eco-hydrauli in Northwest Arid Region of China, Xi'an University of Technology Jian Wang Northwest A\&F University: Northwest Agriculture and Forestry University

Ming Li ( $D$ lileaf@163.com)

Northwest Agriculture and Forestry University https://orcid.org/0000-0002-3939-6036

\section{Research Article}

Keywords: freshwater eutrophication, groundwater chemistry, water quality index, tracer ion, heavy metal, dissolved organic matter

Posted Date: August 9th, 2021

DOl: https://doi.org/10.21203/rs.3.rs-731232/v1

License: (c) (i) This work is licensed under a Creative Commons Attribution 4.0 International License. Read Full License 
1 Groundwater hydrochemical characteristics in a plain river network region: Effects of

2 dissolved organic carbon and possible traceability of pollution sources

6 Ning Ma ${ }^{\text {a }}$, Li Gao ${ }^{\text {b }}$, Zhengkui Ge ${ }^{\text {a }}$, En Hu ${ }^{\mathrm{c}}$, Baozhu Pan ${ }^{\mathrm{d}}$, Jian Wang ${ }^{\mathrm{a}}$, Ming $\mathrm{Li}^{\text {a, }}$ *

$10 \quad{ }^{a}$ College of Natural Resources and Environment, Northwest A \& F University, Yangling

11712100, PR China

$12{ }^{\mathrm{b}}$ Institute for Sustainable Industries and Liveable Cities, Victoria University, PO Box 14428,

13 Melbourne, Victoria 8001, Australia

$14{ }^{\mathrm{c}}$ Shaanxi Provincial Academy of Environmental Science, Xi'an, 710061, PR China

$15{ }^{\mathrm{d}}$ State Key Laboratory of Eco-hydraulic in Northwest Arid Region of China, Xi'an University of Technology, Xi'an, 710048, Shaanxi, China

*Corresponding authors: Ming Li, Email: lileaf@163.com, lileaf@nwsuaf.edu.cn; 
The chemical composition of groundwater indicates the water quality and provides useful information for identifying pollution sources. The aim of this study was to explore the effects of dissolved organic matter inputs on the ionic composition of groundwater and identify ions that can be used as indicators of pollution sources. Descriptive statistics, a Piper diagram, a Gibbs plot, major ion ratios, and Pearson's correlation coefficients were used to analyze the chemical data of 40 groundwater samples collected from the shallow aquifer surrounding Lake Taihu. The results showed that the water quality index values of most sampling points were less than 50 (excellent water quality), except for one point in the southeast direction of the lake basin (good water quality). The dominant hydrochemical type of groundwater was groundwater in the study area.

Keywords: freshwater eutrophication, groundwater chemistry, water quality index, tracer 
Declarations

45 Ethics approval and consent to participate

$46 \quad$ Not applicable

47

48 Consent for publication

49 Not applicable

50

Availability of data and materials

All data generated or analyzed during this study are included in this published article.

\section{Competing interests}

The authors declare that they have no competing interests.

\section{Funding}

This work was supported by the National Natural Science Foundation of China (51979236 and 41771308) and the Open Fund of State Key Laboratory of Eco-hydraulics in Northwest Arid Region (2019KFKT-1). ML was also funded as Tang Scholar by Cyrus Tang Foundation and Northwest A\&F University. The data that support the findings of this study are available from the corresponding author upon request.

\section{Authors' contributions}

ML conceived the study. LG and EH designed the experiment. NM and ZG conducted sample collection. NM and ZG analyzed the sample. NM carried out the data analysis. NM, LG and ML wrote the paper. ML, BP and JW revised the paper. All authors read and approved the 
68 final manuscript.

69

\section{Acknowledgements}

71 This work was supported by the National Natural Science Foundation of China (51979236 and 41771308) and the Open Fund of State Key Laboratory of Eco-hydraulics in Northwest

73 Arid Region (2019KFKT-1). ML was also funded as Tang Scholar by Cyrus Tang Foundation 74 and Northwest A\&F University. The data that support the findings of this study are available 75 from the corresponding author upon request. 


\section{Introduction}

Groundwater is an important water resource and has become a vital reserve source of domestic water, agricultural irrigation, and industrial water. Particularly in arid and semi-arid areas, groundwater might be the only source of water supply (Konikow et al. 2005). However, climate change and human activities have severely affected the quality and ionic composition of groundwater, which has influenced the use of groundwater resources and poses a threat to human health (Bam and Bansah 2020; Ravikumar et al. 2011). Therefore, understanding changes in the quality and ionic composition of groundwater, and determining possible pollution sources for the utilization and protection of groundwater resources, are essential.

Groundwater quality is mainly measured using physical indicators, such as total dissolved solids (TDS) and electrical conductivity (EC), chemical indicators, such as chemical oxygen demand, nitrate $\left(\mathrm{NO}_{3}{ }^{-}\right)$concentration, and heavy metal concentrations, and biological indicators, such as total coliforms and total bacteria (Brezonik and Arnold 2012). The water quality index (WQI), which incorporates multiple indicators, is often used to evaluate groundwater quality globally (Vasanthavigar et al. 2010; Tiwari et al. 2015; Lagnika et al. 2016). The hydrochemical characteristics of groundwater refer to the composition, concentration, and proportion of major ions $\left(\mathrm{K}^{+}, \mathrm{Ca}^{2+}, \mathrm{Na}^{+}, \mathrm{Mg}^{2+}, \mathrm{Cl}^{-}, \mathrm{SO}_{4}{ }^{2-}, \mathrm{HCO}_{3}^{-}\right.$, and $\mathrm{CO}_{3}{ }^{2-}$ ), which comprehensively indicate the regional effects of various factors, such as geology, geomorphology, hydrology, and biochemistry (Chen et al. 2002). The ionic composition of groundwater is useful for evaluating the hydrochemical type of groundwater, monitoring changes in the water chemical structure, and predicting ion sources (Brezonik and Arnold 2012). 

(Alyamani and Hussein 1995; Chen et al. 2019). Shallow groundwater can be recharged either by precipitation infiltration or surface water (Keesari et al. 2021; Wang et al. 2021). In shallow aquifers, rainfall infiltration leaches migratory ions (such as $\mathrm{NO}_{3}{ }^{-}, \mathrm{Cl}^{-}, \mathrm{K}^{+}$, and $\mathrm{Na}^{+}$) from the vadose zone, causing the ion concentrations in groundwater to increase (Ma et al. 2021). Surface water carries pollutants and major ions into shallow aquifers, which alters the quality and ionic composition of groundwater (Alyamani et al. 1995; Subramani et al. 2010). Many studies have shown that groundwater is seriously polluted by organic matter from wastewater and fertilizers (Chen et al. 2010; Li et al. 2014; Shen et al. 2015). In particular, high organic matter inputs alter groundwater quality and ion concentrations (Ham and Tamiya 2006; Halim et al. 2009). Ham et al. (2006) analyzed groundwater samples in an alluvial fan area in Tsukui, Central Japan, between 1999 and 2003. The authors found that the Se concentration was significantly positively correlated with the dissolved organic carbon (DOC) concentration in groundwater, with the main factors influencing Se concentration being DOC concentration, groundwater level, and recharge source. Therefore, exploring the relationship between pollutants and DOC is crucial for the protection and rational use of groundwater.

Local human pollution activity is also an important factor affecting groundwater quality and ionic composition (Lee and Song 2007; Wisitthammasri et al. 2020; Vaiphei and Kurakalva, 2021). Wisitthammasri et al. (2020) showed that, in an aquifer located in Saraburi, Thailand, the $\mathrm{PO}_{4}{ }^{3-}$ concentration in groundwater was not only related to apatite dissolution, but also closely linked to human activities, such as sewage irrigation and fertilizer application. Similarly, Vaiphei and Kurakalva (2021) found that serious nitrate pollution of groundwater 
occurred in an intensive agricultural region of India, and that leaching of agricultural fertilizers was among the most important sources of nitrate. The hydrochemical characteristics can show the potential sources of groundwater pollutants. As early as 1993, the Eastern Coal Geology Corporation found that the groundwater in Hunchun Basin was polluted by $\mathrm{Fe}, \mathrm{Mn}$, and $\mathrm{NO}_{3}{ }^{-}-\mathrm{N}$. Subsequently, Woo et al. (2000) showed that the $\mathrm{Cd}$ and $\mathrm{F}$ concentrations in groundwater in the same area also exceeded the standard levels, with groundwater pollution often associated with anthropogenic activities.

Lake Taihu is often referred to as 'the land flowing with milk and honey' in China. This lake basin is a typical plain river network region that includes the third largest freshwater lake in China and nourishes more than 20 million people (Qin et al. 2007). Owing to the high intensity of industrial and agricultural production, rivers and lakes in this region are facing serious problems from eutrophication. Therefore, analyzing the groundwater quality and identifying potential pollution sources in this region is imperative for protecting water resources. Therefore, the aim of this study was to: investigate whether organic matter inputs from recharge sources around Lake Taihu affect the ionic composition of shallow groundwater, and explore whether specific ions can be used as tracers to indicate the sources of pollutants in groundwater.

\section{Methods and Materials}

\section{Study area and sample collection}

The Lake Taihu Basin is located in the middle and lower reaches of the Yangtze River, with a mean water depth of $1.9 \mathrm{~m}$ (Qin et al. 2007). The Yangtze River basin comprises various 
sedimentary rock systems from the present Cambrian period to the Quaternary period, mainly carbonate, evaporite, and terrestrial clastic rocks, with carbonate rocks being dominant (Xia et al. 2008).

In August 2018, groundwater samples were collected from 40 wells located in the northeast (NE), northwest (NW), southeast (SE), and southwest (SW) directions of Lake Taihu (Fig. 1). The depth of these wells was approximately $5 \mathrm{~m}$, and the sampling depth was $0.5-1 \mathrm{~m}$ below the water surface. Ten sampling points were selected in each direction, and the distance from the sampling point to the shore of Lake Taihu was in the range of 0-43.09 km.

\section{Chemical analysis}

A portable multifunctional parameter meter (Mettler Toledo AG, Zurich, Switzerland) was used to measure the $\mathrm{pH}, \mathrm{EC}$, and TDS of groundwater in situ. In situ determination of biocarbon $\left(\mathrm{HCO}_{3}^{-}\right.$) was performed using the titration method with $0.02 \mathrm{~mol} \mathrm{~L}^{-1} \mathrm{HCl}$ (Wei et al. 2020). Groundwater samples were collected using $1,000-\mathrm{mL}$ polyethylene bottles, stored at $<16^{\circ} \mathrm{C}$, and transported back to the laboratory as soon as possible. The water samples were filtered through precleaned $0.45-\mu \mathrm{m}$ Millipore membranes and the filtrates were stored at $4^{\circ} \mathrm{C}$ for two weeks to complete all chemical analyses.

Major cations $\left(\mathrm{K}^{+}, \mathrm{Ca}^{2+}, \mathrm{Na}^{+}, \mathrm{Mg}^{2+}\right)$ and heavy metal(loid)s $(\mathrm{Cr}, \mathrm{Cu}, \mathrm{Zn}, \mathrm{As}, \mathrm{Cd}$, and $\mathrm{Pb}$ ) were determined by inductively coupled plasma-mass spectrometry (ICAP Qc; ThermoFisher, Waltham, MA, USA). Major anions $\left(\mathrm{Cl}^{-}, \mathrm{SO}_{4}{ }^{2-}\right.$, and $\left.\mathrm{NO}_{3}{ }^{-}\right)$were analyzed by ion chromatography (ICS-1100; Dionex, Sunnyvale, CA, USA). Total dissolved nitrogen (TDN) and total dissolved phosphorus (TDP) concentrations were measured in accordance with the Standard Methods for the Examination of Wastewater (APHA, 2005). DOC concentration 
was measured using a total organic carbon analyzer (TOC-L CPN; Shimadzu, Kyoto, Japan).

All reagents used in this study were analytically pure, and standard solutions were prepared using Milli-Q water. Furthermore, all experimental devices were precleaned using 5\% concentrated nitric acid solution and rinsed with Milli-Q water.

\section{Water quality index calculation}

Groundwater quality was evaluated using the WQI, which was calculated as follows (Saleh et al. 2017; Derdour et al. 2020).

(1) Calculation of proportional weight $\left(W_{i}\right)$ :

$$
W_{i}=w_{i} / \sum_{i=1}^{n} w_{i}
$$

where $W_{i}$ is the proportional weight of the $i$ th chemical parameter, $w_{i}$ is the weight of the $i$ th parameter, and $n$ is the number of parameters tested in this study ( $n=17$; Table S1).

(2) Calculation of the quality rating scale:

$$
q_{i}=\left(C_{i} / S_{i}\right) \times 100
$$

where $q_{i}$ is the quality rating based on the $i$ th chemical parameter, $C_{i}$ is the value of the $i$ th parameter, and $S_{i}$ is the drinking water standard for the $i$ th parameter.

(3) Determining the sub-index value:

$$
S I_{i}=W_{i} \times q_{i}
$$

(4) Calculation of the WQI value:

$$
W Q I=\sum_{i=1}^{n} S I_{i}
$$

where $S I_{i}$ is the sub-index of the $i$ th chemical parameter and $n$ is the number of parameters tested $(n=17)$.

The water quality was classified into five classes according to the calculated WQI values 
(Vasanthavigar et al. 2010; Derdour et al. 2020), as follows: Excellent (WQI < 50); good $(\mathrm{WQI}=50-100)$; poor $(\mathrm{WQI}=100-200)$; very poor $(\mathrm{WQI}=200-300)$; and unsuitable for drinking (WQI > 300).

\section{Hydrochemical analysis}

To identify the hydrochemical type of groundwater, a Piper diagram was constructed based on the concentrations of $\mathrm{Mg}^{2+}, \mathrm{Ca}^{2+}, \mathrm{Na}^{+}, \mathrm{K}^{+}, \mathrm{Cl}^{-}, \mathrm{SO}_{4}{ }^{2-}, \mathrm{CO}_{3}{ }^{2-}$, and $\mathrm{HCO}_{3}{ }^{-}$. The diamond part of the Piper diagram was divided into four regions, representing $\mathrm{Ca}-\mathrm{Mg}-\mathrm{HCO}_{3}$, $\mathrm{Ca}-\mathrm{Mg}-\mathrm{SO}_{4}, \mathrm{Na}-\mathrm{SO}_{4}$, and $\mathrm{Na}-\mathrm{HCO}_{3} \cdot \mathrm{SO}_{4}$ types of groundwater (Piper, 1944). A Gibbs plot was used to distinguish the factors influencing groundwater hydrochemistry, which mainly included precipitation dominance, rock dominance, and evaporation crystallization dominance (Gibbs, 1970). In the Gibbs plot, the weight ratio of $\mathrm{Cl}^{-} /\left(\mathrm{Cl}^{-}+\mathrm{HCO}_{3}^{-}\right)$or $\mathrm{Na}^{+} /\left(\mathrm{Na}^{+}+\mathrm{Ca}^{2+}\right)$ was plotted on the $x$-axis and the TDS was plotted on the $y$-axis.

\section{Statistical analysis}

Statistical analyses were performed using the IBM SPSS Statistics software 25.0 (IBM Corp. Armonk, NY, USA). Pearson's correlation and regression analyses were used to examine the relationships between variables, with a p-value of 0.05 used to determine significance. Origin 2017 (OriginLab Corp. Northampton, MA, USA) and Microsoft Excel 2020 were used to analyze data and draw graphs. Correlation matrices were graphed using the corrplot package in R 4.0.2 (http://www.r-project.org/). A map of the sampling points was created using ArcGIS 10.6 (ESRI Inc. Redlands, CA, USA).

\section{Results}

\section{Water quality characteristics}


$212 \mathrm{mg} \mathrm{L}^{-1}$ (SW10), with a mean value of $7.73 \mathrm{mg} \mathrm{L}^{-1}$ (Fig. 2a). The TDN (Fig. 2b) and $\mathrm{NO}_{3}^{-}$ 213 (Fig. 2d) concentrations were in the range of $0.18-8.62 \mathrm{mg} \mathrm{L}^{-1}$ (mean, $2.61 \mathrm{mg} \mathrm{L}^{-1}$ ) and $214 \quad 0.00-11.50 \mathrm{mg} \mathrm{L}^{-1}$ (mean, $2.92 \mathrm{mg} \mathrm{L}^{-1}$ ), respectively. The TDP concentrations (Fig. 2c) 215 ranged from $0.00-0.49 \mathrm{mg} \mathrm{L}^{-1}$, with a mean value of $0.07 \mathrm{mg} \mathrm{L}^{-1}$, and values in the SE direction were significantly higher $(\mathrm{p}<0.05)$ than those in the SW direction of Lake Taihu.

The concentration ranges of heavy metal(loid)s in the groundwater samples are shown in Fig. S1. A significant difference $(p<0.05)$ in $\mathrm{Cr}$ concentrations was observed between the NE and NW, SW, or SE directions of Lake Taihu. Furthermore, the Pb concentration in the SW direction was significantly lower $(\mathrm{p}<0.05)$ than those in the SW, NE, and SE directions of Lake Taihu.

To assess the groundwater quality, the WQI was calculated for groundwater at the 40 sampling points. The WQI values were in the range of $13.29-56.25$, with a mean value of 29.32 (Fig. S2). Among the 40 sampling points, only SE10 had WQI > 50, which indicated good water quality. At the other sampling points, the WQI values were $<50$, indicating the excellent quality of shallow groundwater in the study area.

\section{Groundwater hydrochemical characteristics} concentrations was observed between the SE and NW, NE, or SW directions of Lake Taihu 
those in the SW direction ( $<<0.05$; Fig. 3f). No significant differences were observed in the concentrations of $\mathrm{Ca}^{2+}, \mathrm{Na}^{+}, \mathrm{Mg}^{2+}, \mathrm{Cl}^{-}, \mathrm{HCO}_{3}{ }^{-}$, and $\mathrm{CO}_{3}{ }^{2-}$ among the four directions of Lake Taihu.

The Piper diagram (Fig. 4) showed that there was no significant difference in the groundwater type among the four directions of Lake Taihu. Most sampling points were located in area IV, meaning that the hydrochemical type of shallow groundwater in the study area was predominantly $\mathrm{Ca}-\mathrm{Mg}-\mathrm{HCO}_{3}$ type. The Gibbs plots (Fig. 5) showed that rock dominance was the major mechanism controlling groundwater chemistry. The TDS concentrations were in the range of $89.70-337.84 \mathrm{mg} \mathrm{L}^{-1}$, with $\mathrm{Cl}^{-} /\left(\mathrm{Cl}^{-}+\mathrm{HCO}_{3}^{-}\right)$and $\mathrm{Na}^{+} /\left(\mathrm{Na}^{+}+\mathrm{Ca}^{2+}\right)$ in the ranges of $0.04-0.43$ and $0.12-0.59$, respectively. concentrations all showed a rapid increase followed by a slow increase $\left(\mathrm{R}^{2}=0.5652,0.6631\right.$, and 0.4621 , respectively); conversely, the $\mathrm{NO}_{3}{ }^{-}$concentration showed a rapid decrease 
followed by a slow decrease $\left(R^{2}=0.2826\right.$; Fig. 7).

Correlations between the major ions and water quality parameters or heavy metals are 
et al. 2010; Ye et al. 2010). For example, $\mathrm{K}^{+}$is generally derived from the weathering and dissolution of potassium feldspar, salt sedimentary rocks, or silicate in aquifers (Yang et al. 2016). $\mathrm{Na}^{+}$is the primary product of the weathering and dissolution of halite, albite, and silicate (Yang et al. 2016), and can be used as an indicator of seawater intrusion or groundwater overexploitation. $\mathrm{Ca}^{2+}$ mainly comes from the dissolution of gypsum $\left(\mathrm{CaSO}_{4} \cdot 2 \mathrm{H}_{2} \mathrm{O}\right)$, anhydrite $\left(\mathrm{CaSO}_{4}\right)$, calcite $\left(\mathrm{CaCO}_{3}\right)$, and dolomite $\left(\mathrm{CaMg}\left(\mathrm{CO}_{3}\right)_{2}\right)($ Chen et al. 2002; Yang et al. 2016).

To further explore the possible origin of major ions and the geochemical process controlling groundwater chemistry (Moussa et al. 2009), the proportional coefficient was analyzed (Fig. S3). In the $\mathrm{Na}^{+}-\mathrm{Cl}^{-}$ratio diagram (Fig. S3a), some sampling points were distributed around the 1:1 line, indicating that halite dissolution was dominant (Meybeck, 1987). However, the distribution of most samples above the 1:1 line indicated that halite dissolution was not the only source of $\mathrm{Na}^{+}$. Indeed, other $\mathrm{Na}^{+}$sources included weathering of sodium silicate and human activity (Yang et al. 2016). Furthermore, the proportional coefficient of $\mathrm{Ca}^{2+}$ and $\mathrm{SO}_{4}^{2-}$ can be used to determine whether $\mathrm{Ca}^{2+}$ and $\mathrm{SO}_{4}^{2-}$ in groundwater originate from the dissolution of gypsum and anhydrite. In the $\mathrm{Ca}^{2+}-\mathrm{SO}_{4}{ }^{2-}$ ratio diagram (Fig. S3c), the distribution of most samples was under the 1:1 line. In addition to gypsum dissolution, other sources of $\mathrm{Ca}^{2+}$ might exist, such as carbonate rocks.

The bivariate plot of $\mathrm{Ca}^{2+}$ versus $\mathrm{HCO}_{3}{ }^{-}$(Fig. S3d) showed that most sampling points were near the 1:1 line. This distribution pattern indicated that $\mathrm{HCO}_{3}{ }^{-}$in the groundwater mainly originated from the dissolution of carbonates (such as calcite and dolomite), while $\mathrm{Ca}^{2+}$ was partly derived from carbonates in the study area. This conclusion was consistent with the 
$\mathrm{Ca}^{2+}-\mathrm{SO}_{4}{ }^{2-}$ ratio results (Fig. S3c). To determine the occurrence of ion-exchange in groundwater, the linear relationship between $\left(\left(\mathrm{Ca}^{2+}+\mathrm{Mg}^{2+}\right)-\left(\mathrm{SO}_{4}{ }^{2-}+\mathrm{HCO}_{3}{ }^{-}\right)\right)$and

$301\left(\mathrm{Na}^{+}+\mathrm{K}^{+}-\mathrm{Cl}^{-}\right)$was analyzed (Yang et al. 2016). Most of the groundwater sampling points around Lake Taihu were near the 1:1 line (Fig. S3f), indicating strong ion-exchange occurring in shallow groundwater in the study area. 
groundwater and creates an anaerobic microenvironment, which is also necessary for the denitrification process to occur. Therefore, the DOC concentration in groundwater affects the redox conditions and $\mathrm{NO}_{3}{ }^{-}$concentration via biotic and abiotic processes. In this study, $\mathrm{Ca}^{2+}$ showed a significant negative correlation with $\mathrm{Na}^{+}, \mathrm{Mg}^{2+}, \mathrm{Cl}^{-}$, and $\mathrm{CO}_{3}{ }^{2-}$, while $\mathrm{Mg}^{2+}$ showed a significant negative correlation with $\mathrm{SO}_{4}{ }^{2-}$. This indicated that $326 \mathrm{Ca}^{2+}$ in groundwater had a different source to $\mathrm{Na}^{+}, \mathrm{Mg}^{2+}, \mathrm{Cl}^{-}$, and $\mathrm{CO}_{3}{ }^{2-}$. In contrast, $\mathrm{Mg}^{2+}$ and $\mathrm{Cl}^{-}$or $\mathrm{CO}_{3}{ }^{2-}$, showing that these ions had the same source. Furthermore, the lack of significant correlation between $\mathrm{K}^{+}$and other major ions (except $\mathrm{Mg}^{2+}$ ) indicated that the source of $\mathrm{K}^{+}$was distinctly different to that of other ions. fertilizer application led to an increase in the $\mathrm{K}^{+}$concentration in groundwater, mainly due to 
Taihu and its surrounding river network is usually $2.00 \mathrm{mg} \mathrm{L}^{-1}$ (Yao et al. 2018), and the mean TN concentration in Lake Taihu is $1.55 \mathrm{mg} \mathrm{L}^{-1}$ (The Health Status Report of Taihu Lake, 2018). In the present study, the mean TDN concentration in groundwater around Lake Taihu (2.61 $\mathrm{mg} \mathrm{L}^{-1}$ ) was higher than that in Lake Taihu and its surrounding river network. Therefore, $\mathrm{NO}_{3}{ }^{-}$leaching from soil in the Lake Taihu Basin might be the main source of $\mathrm{NO}_{3}{ }^{-}$in groundwater. were similar to that of $\mathrm{K}^{+}$. Therefore, both As and $\mathrm{Cd}$ might come from the use of fertilizers in agricultural production. The extensive application of fertilizers can increase the content of turn promoted As release from sediment. Furthermore, Campos (2002) studied the influence

The results of this study also showed a significant positive correlation between the concentrations of $\mathrm{K}^{+}$and $\mathrm{As}$ or $\mathrm{Cd}$, indicating that the sources of $\mathrm{As}$ and $\mathrm{Cd}$ in groundwater heavy metal(loid)s, including As and Cd, in soil and groundwater (Nicholsonet al. 2003; Atafar et al. 2008; Belon et al. 2012; Kubier et al. 2019). A previous study has shown that $\sim 30 \%-35 \%$ of $\mathrm{Cd}$ in the groundwater of an agricultural region comes from mineral fertilizers (Belon et al. 2012). Boudaghi et al. (2012) studied changes in heavy metals in groundwater before and after fertilization of paddy soil, finding an increase in the concentration of heavy metals after fertilization; the results showed a significant positive correlation between the $\mathrm{Cd}$ concentration and amount of potassium fertilizers applied.

Uddin and Kurosawa (2011) investigated the effects of nitrogen fertilizer application on As pollution in groundwater in Bangladesh, finding that a high- $\mathrm{N}$ environment created by fertilizers led to reducing conditions in the groundwater through microbial activity, which in of phosphate fertilizer application on groundwater pollution by As in Sao Paulo, Brazil, with 
the results showing that As element as an undesirable additive in phosphatic fertilizers was a source of As in groundwater. In summary, As and Cd in the groundwater of Lake Taihu have similar sources, and are likely derived from the application of chemical fertilizers in agricultural production. Considering their close relationship, $\mathrm{K}^{+}$can be used as a tracer ion for the sources of As and Cd in shallow groundwater in the study area.

In this study, the concentrations of all major ions, except $\mathrm{K}^{+}$, were positively correlated with the $\mathrm{Pb}$ concentration in groundwater. The sources of dissolved $\mathrm{Pb}$ in groundwater mainly include water-rock interactions in aquifers and industrial or agricultural activities (Millot and Négrel 2015). Furthermore, $\mathrm{Pb}$ can be emitted into the atmosphere by industries and automobiles, then deposited on the soil in the form of wet or dry sedimentation, and further 
chemistry. The groundwater was mainly $\mathrm{Ca}-\mathrm{Mg}-\mathrm{HCO}_{3}$ type, and there was no significant difference in the hydrochemical type of groundwater among the four directions of the lake basin.

(ii) High levels of organic matter were observed in Lake Taihu and its surrounding river network due to eutrophication, and a large amount of organic matter input to groundwater accelerated the activities of microorganisms and altered the redox conditions of the groundwater. These environmental changes, in turn, accelerated the dissolution of rocks and minerals, and changed the concentrations of ions in groundwater, which affected the hydrochemical type of groundwater.

(iii) The concentrations of heavy metal(loid)s in groundwater were closely linked to human activities. $\mathrm{K}^{+}$, As, and $\mathrm{Cd}$ in the study area were mainly derived from the application of chemical fertilizers, and $\mathrm{K}^{+}$can be used as indicator ion for the sources of As and $\mathrm{Cd}$ in groundwater. $\mathrm{Pb}$ in the groundwater around Lake Taihu mainly originated from water-rock interactions in the aquifer.

\section{Acknowledgements}

This work was supported by the National Natural Science Foundation of China (51979236 and 41771308) and the Open Fund of State Key Laboratory of Eco-hydraulics in Northwest Arid Region (2019KFKT-1). ML was also funded as Tang Scholar by Cyrus Tang Foundation and Northwest A\&F University. The data that support the findings of this study are available from the corresponding author upon request. 


\section{References}

Alyamani MS, Hussein MT (1995) Hydrochemical study of groundwater in recharge area, Wadi Fatimah basin, Saudi Arabia. GeoJournal. 37(1):81-89. https://doi.org/10.1007/BF00814887

Atafar Z, Mesdaghinia A, Nouri J, Homace M, Yunesian M, Ahmadimoghaddam M, Mahvi AH (2010) Effect of fertilizer application on soil heavy metal concentration. Environmental Monitoring \& Assessment. 160(1-4):83. https://doi.org/10.1007/s10661-008-0659-x

Bam E, Bansah S (2020) Groundwater Chemistry and Isotopes reveal Vulnerability of Granitic Aquifer in the White Volta River Watershed (West Africa). Applied Geochemistry. 119(6):104662. https://doi.org/10.1016/j.apgeochem.2020.104662

Belon E, Boisson M, Deportes IZ, Eglin TK, Feix I, Bispo AO, Galsomies L, Leblond S, Guellier CR (2012) An inventory of trace elements inputs to French agricultural soil. Science of The Total Environment. 439:87-95. https://doi.org/10.1016/j.scitotenv.2012.09.011

Boudaghi H, Yunesian M, Mahvi AH, Mohammadi MA, Dehghani MH, Nazmara S (2012) Cadmium, lead and arsenic concentration in soil and underground water and its relationship with chemical fertilizer in paddy soil. J. Mazandaran Univ. Med. Sci. 21(1):20-28.

Brezonik PL, Arnold,WA (2012) Water chemistry: fifty years of change and progress. $\begin{array}{lllll}\text { Environmental } & \text { Science } \quad \& \quad \text { Technology. 46(11):5650-5657. }\end{array}$ https://doi.org/10.1021/es300882y 
Campos V (2002). Arsenic in groundwater affected by phosphate fertilizers at Sao Paulo, $\begin{array}{llll}\text { Brazil. } & \text { Environmental } & \text { Geology. }\end{array}$ https://doi.org/10.1007/s00254-002-0540-0

Chen J, Qian H, Gao YY, Wang HK, Zhang MS (2019) Insights into hydrological and hydrochemical processes in response to water replenishment for lakes in arid regions. Journal of Hydrology. 581. https://doi.org/10.1016/j.jhydrol.2019.124386

Chen JS, Wang FY, Xia XH, Zhang LT (2002) Major element chemistry of the Changjiang (Yangtze River). Chemical Geology. 187(3):231-255. https://doi.org/10.1016/S0009-2541(02)00032-3

Chen ML, Price RM, Yamashita Y, Jaffé R (2010) Comparative study of dissolved organic matter from groundwater and surface water in the Florida coastal everglades using multi-dimensional spectrofluorometry combined with multivariate statistics. Applied Geochemistry. 25 (6):872-880. https://doi.org/10.1016/j.apgeochem.2010.03.005

Datta PS, Deb DL, Tyagi SK (1997) Assessment of groundwater contamination from fertilizers in the Delhi area based on $180, \mathrm{NO}_{3}{ }^{-}$and $\mathrm{K}^{+}$composition. Journal of Contaminant Hydrology. 27(3):249-262. https://doi.org/10.1016/S0169-7722(96)00099-X

Derdour A, Ali MMM, Sari SMC (2020) Evaluation of the quality of groundwater for its appropriateness for drinking purposes in the watershed of Nama, SW of Algeria, by using water quality index (WQI). SN Applied Sciences. 2(12):1951. https://doi.org/10.1007/s42452-020-03768-x

Eastern Coal Geology Corporation: 1993, The Second Water-Resource Survey in Hunchun 
Area. Hunchun City, Jirin Province.

Gibbs RJ (1970) Mechanisms Controlling World Water Chemistry. Science. 170. https:// doi.org/10.1126/science.170.3962.1088

Halim MA, Majumder RK, Nessa SA, Hiroshiro Y, Uddin MJ, Shimada J, Jinno K (2009) Hydrogeochemistry and arsenic contamination of groundwater in the Ganges Delta Plain, Bangladesh. Journal of Hazardous Materials. 164(2-3):1335-1345. https:// doi.org/10.1016/j.jhazmat.2008.09.046

Ham YS, Tamiya S (2006) Selenium behavior in open bulk precipitation, soil Solution and groundwater in alluvial fan area in Tsukui, central Japan. Water Air \& Soil Pollution. 177(1-4):45-57. https://doi.org/10.1007/s11270-005-9062-1

Hofmann R, Griebler C (2018) DOM and bacterial growth efficiency in oligotrophic groundwater: Absence of priming and co-limitation by organic carbon and phosphorus. Aquatic Microbial Ecology. 81 (1):55-71. https://doi.org/10.3354/ame01862

Keesari T, Sinha UK, Saha D, Dwivedi SN, Shukla RR, Mohokar H, Roy A (2021) Isotope and hydrochemical systematics of groundwater from multi-tiered aquifer in central parts of Indo-Gangetic Plains, India - implications on groundwater sustainability and security. $\begin{array}{lllll}\text { Science } & \text { of } & \text { The } & \text { Total } & \text { Environment. }\end{array}$ https://doi.org/10.1016/j.scitotenv.2021.147860

Konikow LF, Kendy E (2005) Groundwater depletion: a global problem. Hydrogeology Journal. 13:317-320. https://doi.org/10.1007/s10040-004-0411-8

Kubier A, Wilkin RT, Pichler T (2019) Cadmium in soils and groundwater: a review. Applied Geochemistry. 108:104388. https://doi.org/10.1016/j.apgeochem.2019.104388 
Lagnika M, Ibikounle M, Boutin C, Sakiti et NG (2016) Groundwater biodiversity and water quality of wells in the Southern region of Benin. Comptes Rendus Chimie. 1-9. https://doi.org/10.1016/j.crci.2015.08.009

Lee JY, Song SH (2007) Groundwater chemistry and ionic ratios in a western coastal aquifer of Buan, Korea: implication for seawater intrusion. Geosci. J eosciences Journal. 11(3):259-270. https:// doi.org/10.1007/BF02913939

Li JX, Wang YX, Guo W, Xie XJ, Zhang LP, Liu YQ, Kong SQ (2014) Iodine mobilization in groundwater system at Datong basin, China: Evidence from hydrochemistry and fluorescence characteristics. Science of the Total Environment. 468-469:738-745. https://doi.org/10.1016/j.scitotenv.2013.08.092

Ma HY, Zhu GF, Zhang Y, Sang LY, Wan QZ, Zhang ZY, Xu YX, Qiu DD (2021) Ion migration process and influencing factors in inland river basin of arid in China: a case study of Shiyang River Basin. Environmental Science and Pollution Research. https://doi.org/10.1007/s11356-021-14484-3

Meybeck M (1983) Atmospheric inputs and river transport of dissolved substances. Dissolved Loads of Rivers \& Surface Water Quantity/quality Relationships, 141.

Millot R, Négrel P (2015) Lead isotope systematics in groundwater: implications for source tracing in different aquifer types. Procedia Earth and Planetary Science. 13:7-10. https://doi.org/10.1016/j.proeps.2015.07.002

Moussa AB, Zouari K, Oueslati N (2009) Geochemical study of groundwater mineralization in the Grombalia shallow aquifer, north-eastern Tunisia: implication of irrigation and industrial waste water accounting. Environmental Geology. 58(3):555-566. https:// 
Nicholson FA, Smith SR, Alloway BJ, Carlton-Smith BJ (2003) An inventory of heavy metals inputs to agricultural soils in England and Wales. Water \& Environment Journal. 311:205-219. https://doi.org/10.1016/S0048-9696(03)00139-6

Piper AM (1944) A graphic procedure in the geochemical interpretation of water analyses. Trans. Eos Transactions American Geophysical Union. 25:914-923. https://doi.org/10.1029/TR025i006p00914

Qin BQ, Xu PZ, Wu QL, Luo LC, Zhang YL (2007) Environmental issues of Lake Taihu, China. Hydrobiologia. 581 (1):3-14. https://doi.org/10.1007/s10750-006-0521-5

Ravikumar P, Venkatesharaju K, Prakash KL, Somashekar RK (2011) Geochemistry of groundwater and groundwater prospects evaluation, Anekal Taluk, Bangalore Urban District, Karnataka, India. Environmental Monitoring and Assessment. 179(1-4):93-112. https://doi.org/ 10.1007/s10661-010-1721-z

Saby N, Arrouays D, Boulonne L, Jolivet C, Pochot A (2006) Geostatistical assessment of Pb in soil around Paris, France. Science of the Total Environment. 367(1):212-221. https://doi.org/10.1016/j.scitotenv.2005.11.028

Shen Y, Chapelle FH, Strom EW, Benner R (2015) Origins and bioavailability of dissolved organic matter in groundwater. Biogeochemistry. 122 (1):61-78. https://doi.org/ $10.1007 / \mathrm{s} 10533-014-0029-4$

Spalding R, Exner ME (1993) Occurrence of Nitrate in Groundwater-A Review. J. Environ. Qual. 22(3):392-402. https://doi.org/10.2134/jeq1993.00472425002200030002x

Subramani T, Rajmohan N, Elango L (2010) Groundwater geochemistry and identification of 
hydrogeochemical processes in a hard rock region, Southern India. Environmental

and

Assessment.

162(1):123-137. https://doi.org/10.1007/s10661-009-0781-4.

The health status report of Taihu Lake, 2018.

Tiwari AK, Singh PK, Mahato MK (2014) GIS-Based Evaluation of Water Quality Index of Ground Water Resources in West Bokaro Coalfield, India. Current World Environment. 9(3):843-850. https://doi.org/10.12944/CWE.9.3.35

Uddin MS, Kurosawa K (2011) Effect of chemical nitrogen fertilizer application on the release of arsenic from sediment to groundwater in Bangladesh. Procedia Environmental Sciences. 4:294-302. https://doi.org/10.1016/j.proenv.2011.03.034

Vaiphei SP, Kurakalva RM (2021) Hydrochemical characteristics and nitrate health risk assessment of groundwater through seasonal variations from an intensive agricultural region of upper Krishna River basin, Telangana, India. Ecotoxicology and Environmental Safety. 213:112073. https://doi.org/10.1016/j.ecoenv.2021.112073

Vasanthavigar M, Srinivasamoorthy K, Vijayaragavan K, Rajiv Ganthi R, Chidambaram S, Anandhan P, Manivannan R, Vasudevan S (2010) Application of water quality index for groundwater quality assessment: Thirumanimuttar sub-basin, Tamilnadu, India. Environmental Monitoring \& Assessment. 171(1-4):595-609. https://doi.org/10.1007/s10661-009-1302-1

Vázquez-Suné E, Sánchez-Vila X, Carrera J (2005) Introductory review of specific factors influencing urban groundwater, an emerging branch of hydrogeology, with reference to Barcelona, Spain. Hydrogeology Journal. $13 \quad$ (3):522-533. 
Wang WK, Zhang ZY, Yin LH, Duan L, Huang JT (2021) Topical Collection: Groundwater recharge and discharge in arid and semi-arid areas of China. Hydrogeology Journal. 29(2):521-524. https://doi.org/10.1007/s10040-021-02308-0

Wei MJ, Duan PF, Gao PC, Guo SL, Hu YX, Yao LG, Li M (2020) Exploration and application of hydrochemical characteristics method for quantification of pollution sources in the Danjiangkou Reservoir area. Journal of Hydrology. 590:125291. https://doi.org/10.1016/j.jhydrol.2020.125291

Wisitthammasri W, Chotpantarat S, Thitimakorn T (2020) Multivariate statistical analysis of the hydrochemical characteristics of a volcano sedimentary aquifer in Saraburi Province, Thailand. Journal of Hydrology: Regional Studies. 32:100745. https://doi.org/10.1016/j.ejrh.2020.100745

Woo NC, Moon JW, Won JS, Hang JS, Lin XY, Zhao YS (2000) Water quality and pollution in the Hunchun Basin, China. Environmental Geochemistry \& Health. 22:1-18. https://doi.org/10.1023/A:1006639920429

Xia XQ, Yang ZF, Wang YP, Ji JF, Li WM (2008) Major ion chemistry in the Yangtze River. Earth Science Frontiers. 15(5):194-202. https://doi.org/10.2749/101686606778026565

Yang QC, Wang LC, Ma HY, Yu K, Martin JD (2016) Hydrochemical characterization and pollution sources identification of groundwater in Salawusu aquifer system of Ordos Basin, China. Environmental 216:340-349. https://doi.org/10.1016/j.envpol.2016.05.076 
Yao XL, Zhang YL, Lu Z, Zhu GW, Qin BQ, Zhou YQ, Xue JY (2020) Emerging role of dissolved organic nitrogen in supporting algal bloom persistence in Lake Taihu, China: Emphasis on internal transformations. Science of The Total Environment. 736:139497. https://doi.org/ 10.1016/j.scitotenv.2020.139497

Ye HM, Yuan XY, Ge MX, Li JZ, Sun H (2010) Water chemistry characteristics and controlling factors in the northern rivers in the Taihu Basin. Ecology and Environmental Sciences, 19(1):23-27. https://doi.org/10.16258/j.cnki.1674-5906.2010.01.004

Zhai Y, Wang CH, Chen G, Wang C, Li XN, Liu YT (2020) Field-based analysis of runoff generation processes in humid lowlands of the Taihu Basin, China. Water. 12(4):1216. https://doi.org/10.3390/w12041216 
Figure captions:

571

572

573

Fig. 1 Location map of the study area (Lake Taihu Basin) and groundwater sampling points $(n=40)$

Fig. 2 Spatial variation in water quality parameters of groundwater in the aquifer surrounding the Lake Taihu Basin: (a) Dissolved organic carbon (DOC); (b) total dissolved nitrogen (TDN); (c) total dissolved phosphorus (TDP); (d) nitrate $\left(\mathrm{NO}_{3}{ }^{-}\right)$. *indicates significant difference between different directions of Lake Taihu $(\mathrm{p}<0.05)$. Line within box, transparent square, and box indicate the median, mean, and $25 \%-75 \%$ interquartile range, respectively.

Fig. 3 Spatial variation in major ion concentrations in groundwater: (a) $\mathrm{K}^{+}$; (b) $\mathrm{Ca}^{2+}$; (c) $\mathrm{Na}^{+}$; (d) $\mathrm{Ma}^{2+}$; (e) $\mathrm{Cl}^{-}$; (f) $\mathrm{SO}_{4}{ }^{2-}$; (g) $\mathrm{HCO}_{3}{ }^{-}$; (h) $\mathrm{CO}_{3}{ }^{2-}$. * indicates significant difference between different directions $(\mathrm{p}<0.05)$. Line within box, transparent square, and box indicate the median, mean, and $25 \%-75 \%$ interquartile range, respectively.

Fig. 4 Piper diagram showing the chemical composition of groundwater samples in the study area.

Fig. 5 Gibbs plots indicating the mechanisms controlling groundwater chemistry in the study area.

Fig. 6 Correlations between the relative proportions of major ions in groundwater. ${ }^{*} p<0.05$, $* * \mathrm{p}<0.01$, and $* * * \mathrm{p}<0.001$

Fig. 7 Correlations between the concentrations of DOC and (a) $\mathrm{Na}^{+}$, (b) $\mathrm{Mg}^{2+}$, (c) $\mathrm{NO}_{3}{ }^{-}$, and (d) $\mathrm{HCO}_{3}{ }^{-}$in groundwater.

Fig. 8 Correlations between the major ions and basic water quality parameters or heavy metals in groundwater. $* \mathrm{p}<0.05, * * \mathrm{p}<0.01$, and $* * * \mathrm{p}<0.001$ 


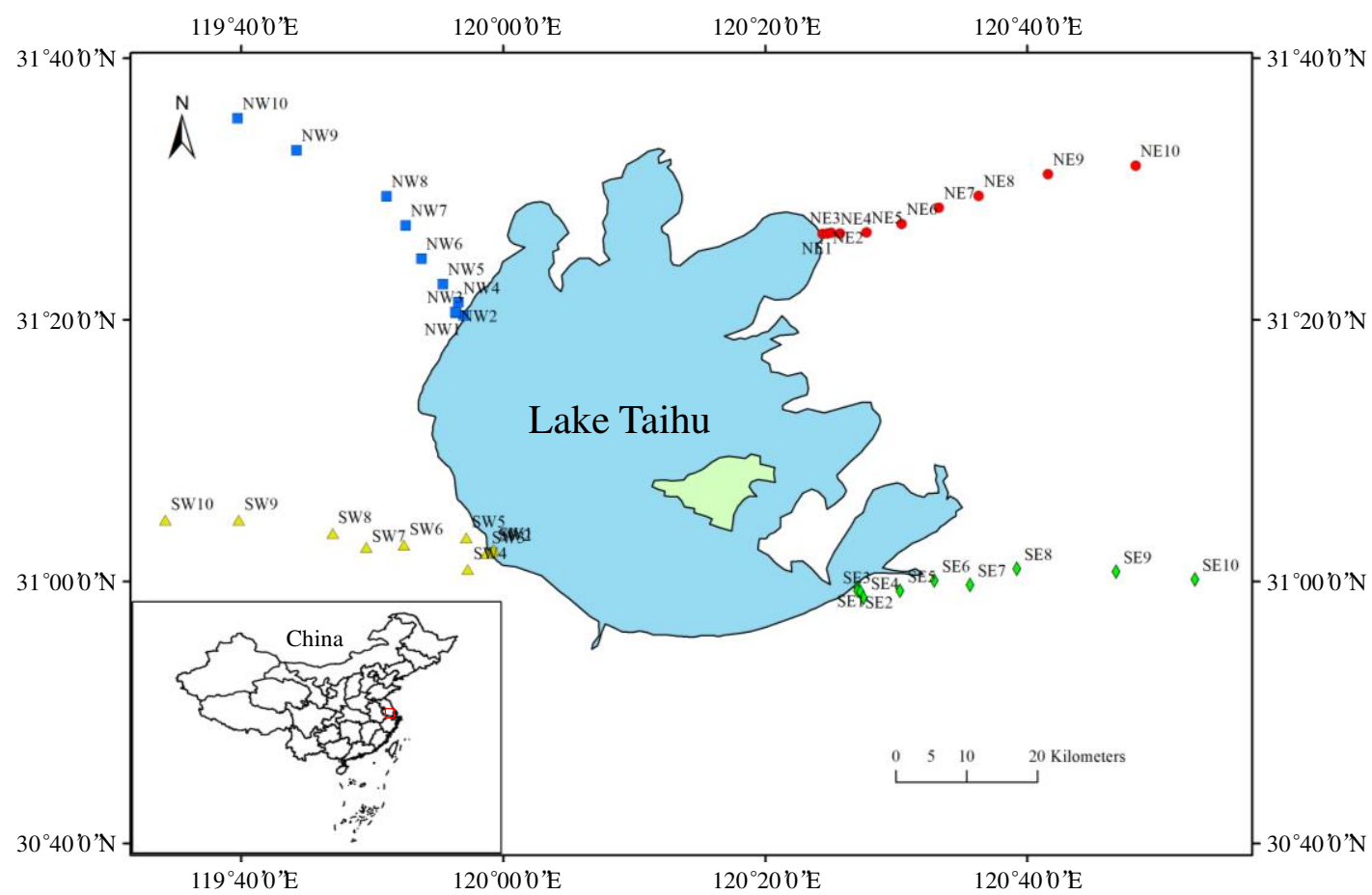

593 Fig. 1 Location map of the study area (Lake Taihu Basin) and groundwater sampling points $594 \quad(n=40)$. 

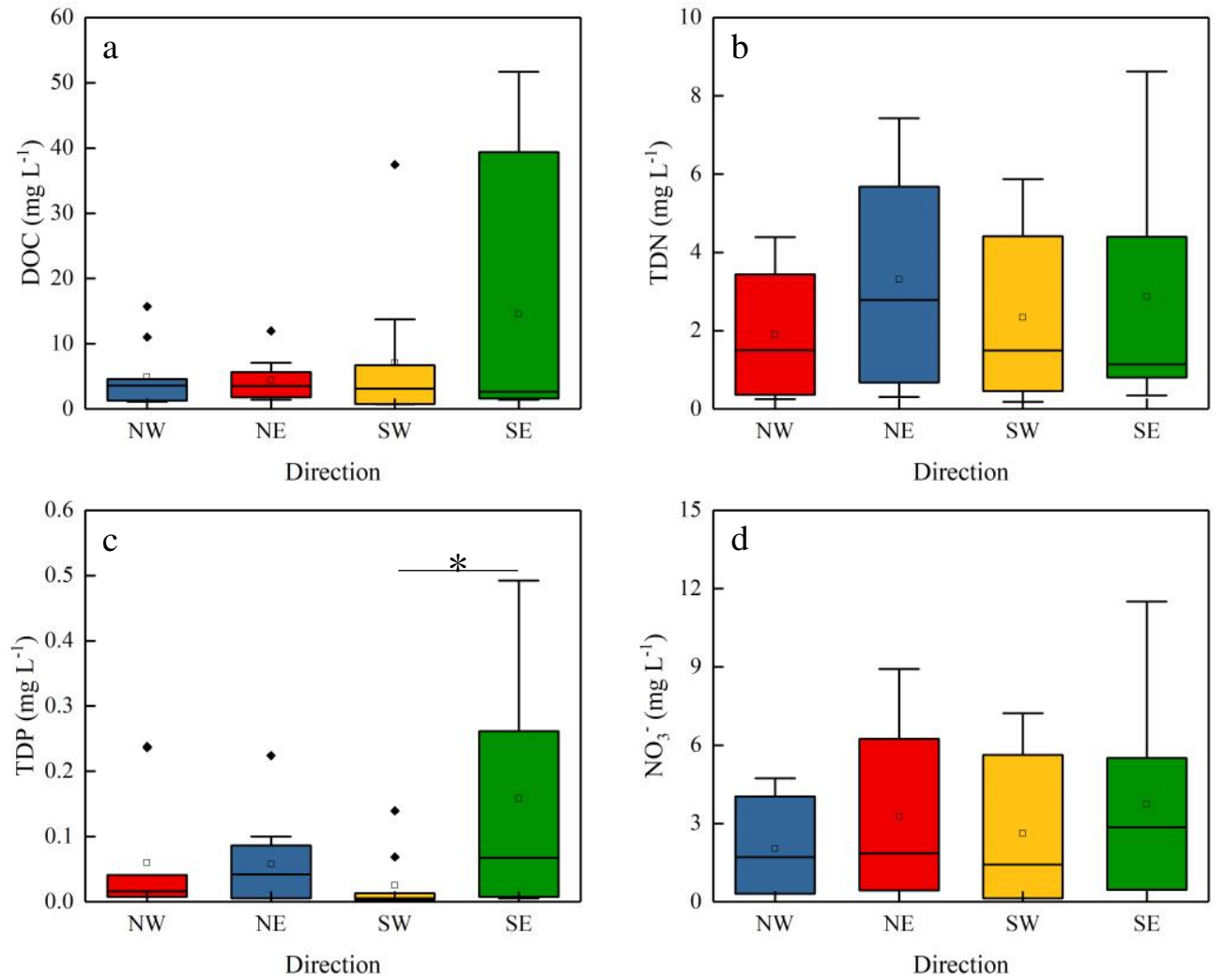

Fig. 2 Spatial variation in water quality parameters of groundwater in the aquifer surrounding

598 the Lake Taihu Basin: (a) Dissolved organic carbon (DOC); (b) total dissolved nitrogen

599 (TDN); (c) total dissolved phosphorus (TDP); (d) nitrate $\left(\mathrm{NO}_{3}{ }^{-}\right)$. *indicates significant

600 difference between different directions of Lake Taihu $(\mathrm{p}<0.05)$. Line within box, transparent

601 square, and box indicate the median, mean, and 25\%-75\% interquartile range, respectively. 

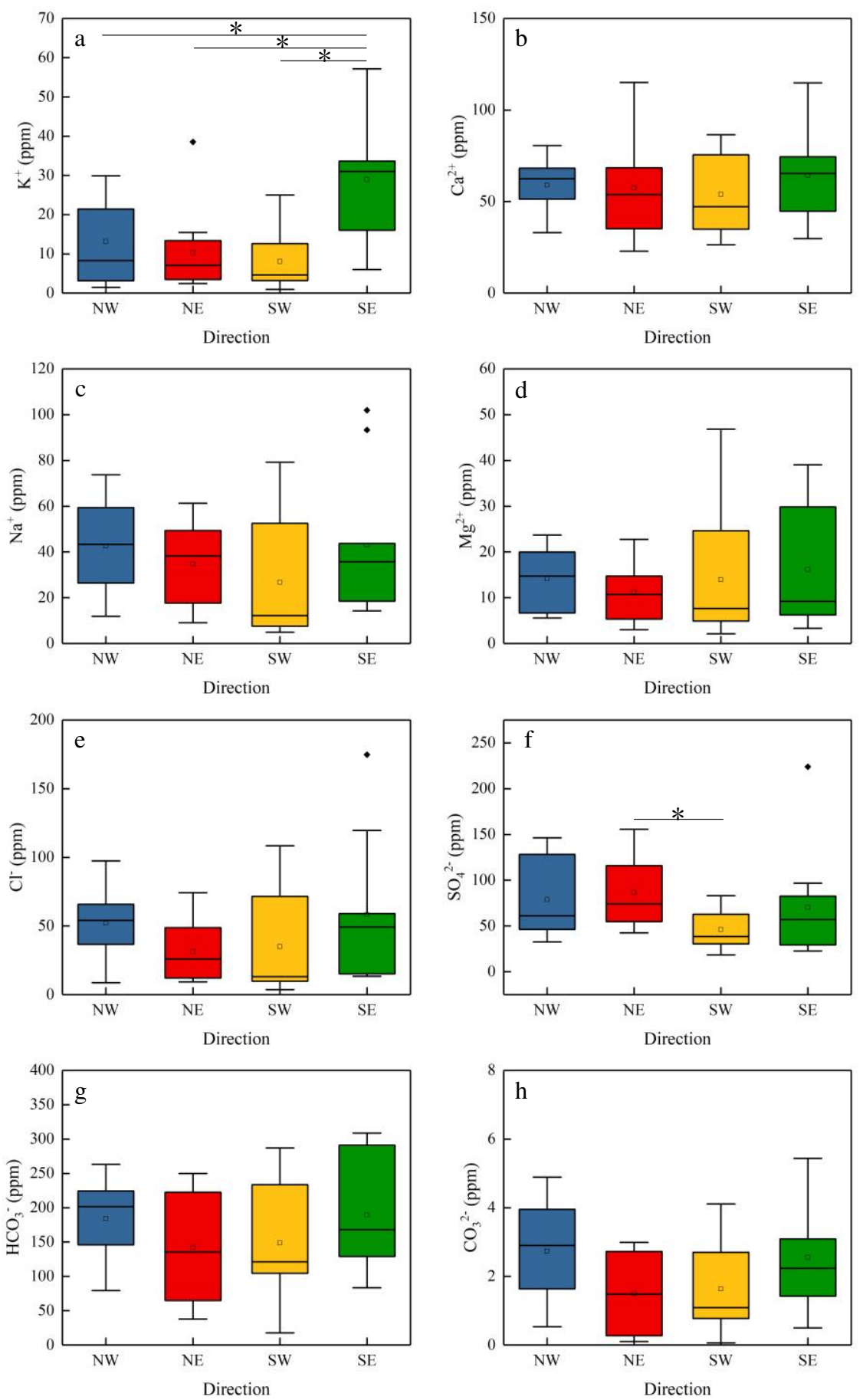

Fig. 3 Spatial variation in major ion concentrations in groundwater: (a) $\mathrm{K}^{+}$; (b) $\mathrm{Ca}^{2+}$; (c) $\mathrm{Na}^{+}$; (d) $\mathrm{Ma}^{2+} ;$ (e) $\mathrm{Cl}^{-}$; (f) $\mathrm{SO}_{4}{ }^{2-} ;$ (g) $\mathrm{HCO}_{3}^{-}$; (h) $\mathrm{CO}_{3}{ }^{2-}$. * indicates significant difference between 606 different directions $(\mathrm{p}<0.05)$. Line within box, transparent square, and box indicate the 607 median, mean, and 25\%-75\% interquartile range, respectively. 


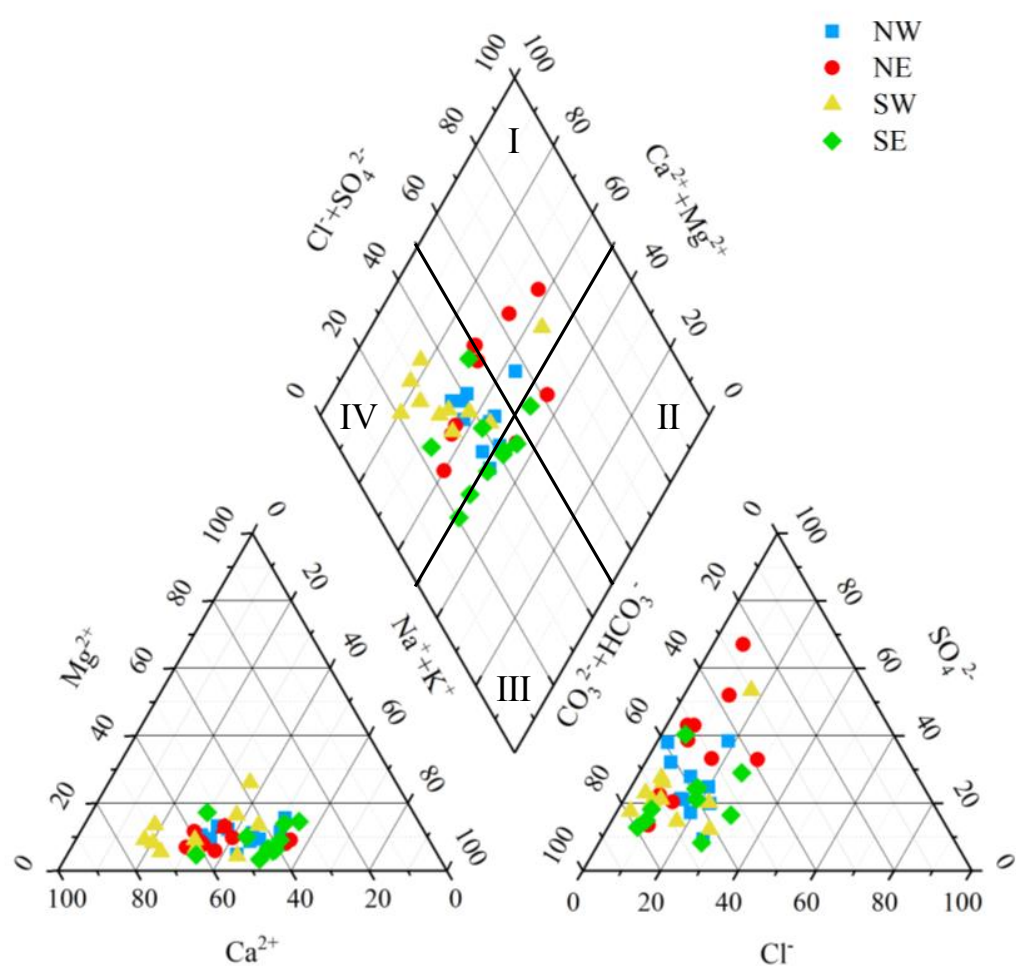

609

610 Fig. 4 Piper diagram showing the chemical composition of groundwater samples in the study 611 area. 

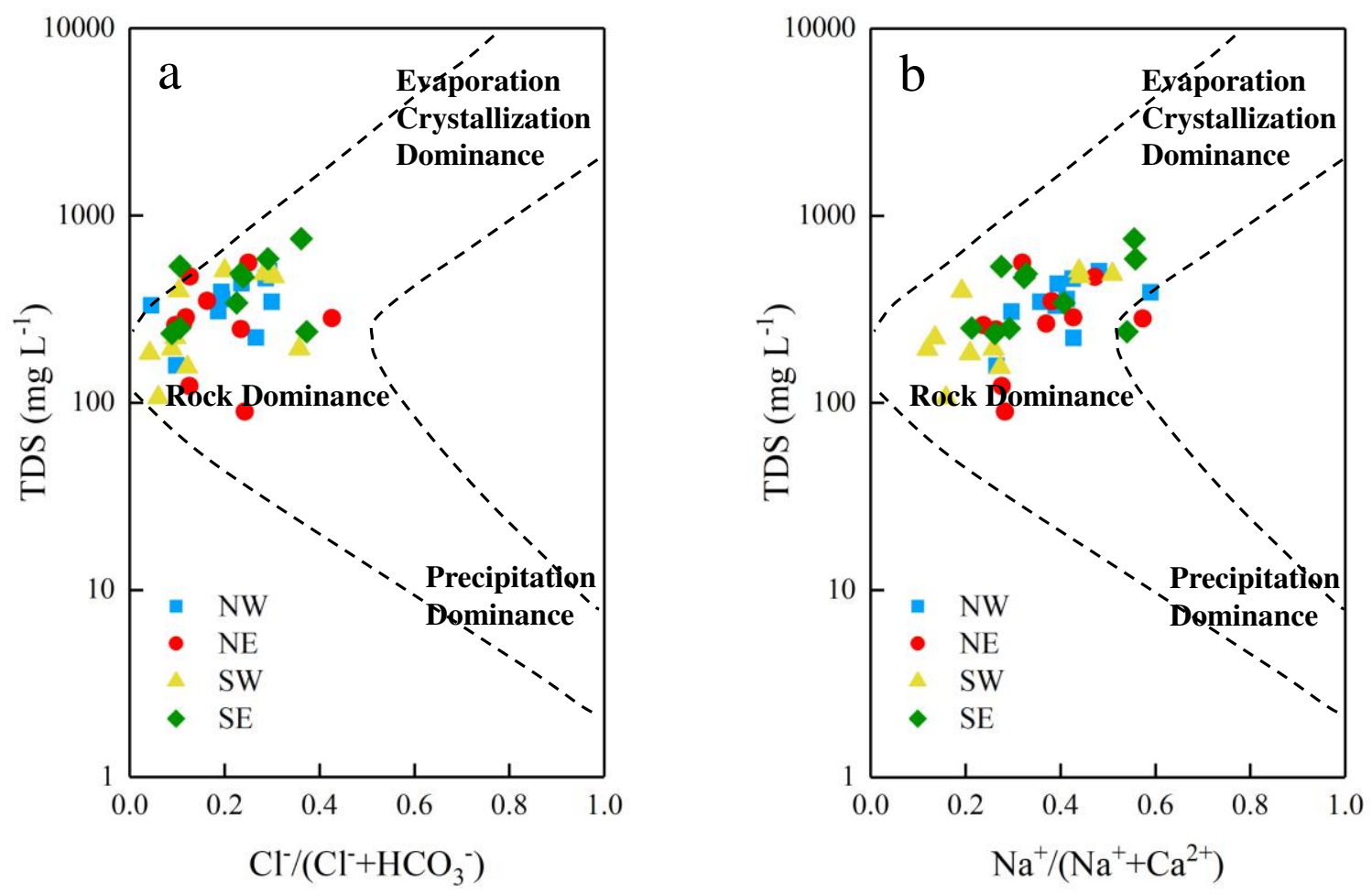

612

613 Fig. 5 Gibbs plots indicating the mechanisms controlling groundwater chemistry in the study 614 area. 


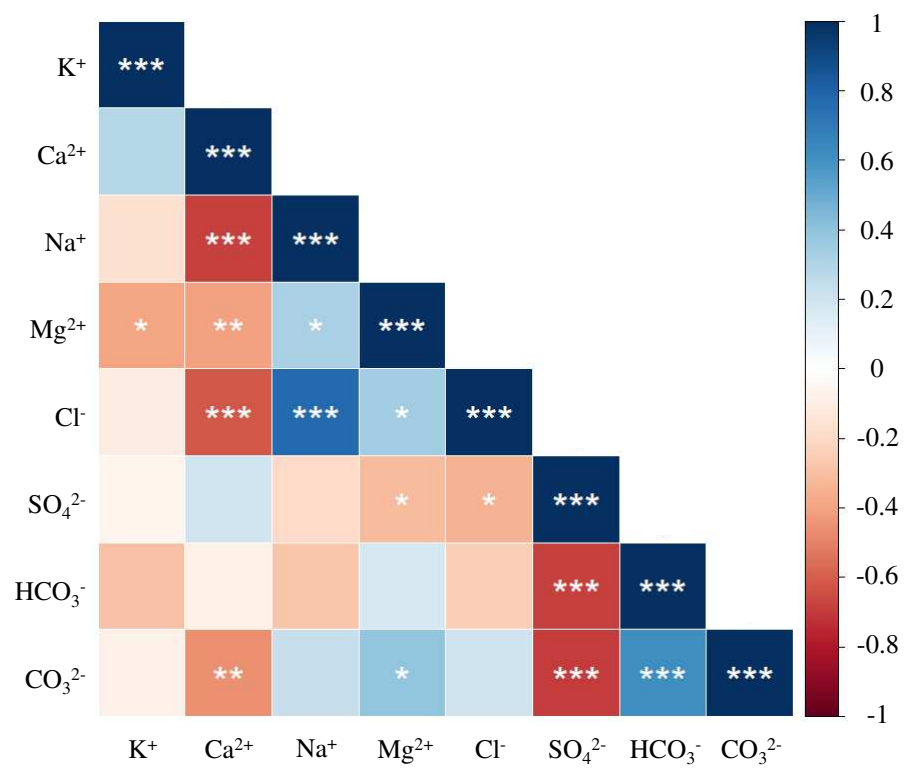

617 Fig. 6 Correlations between the relative proportions of major ions in groundwater. ${ }^{*} \mathrm{p}<0.05$, $618 * * \mathrm{p}<0.01$, and ***p $<0.001$

619 

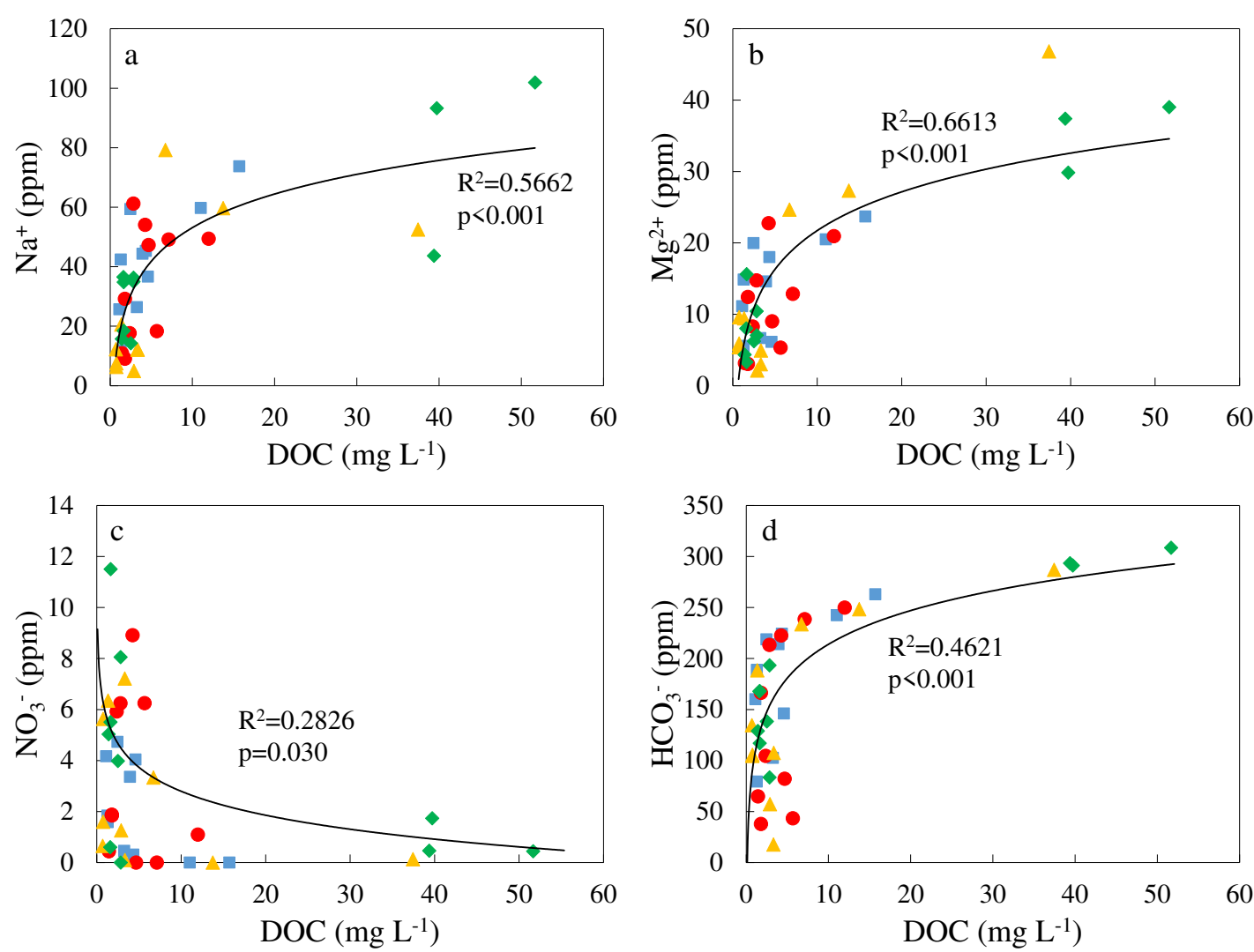

620

Fig. 7 Correlations between the concentrations of DOC and (a) $\mathrm{Na}^{+}$, (b) $\mathrm{Mg}^{2+}$, (c) $\mathrm{NO}_{3}{ }^{-}$, and

(d) $\mathrm{HCO}_{3}{ }^{-}$in groundwater.

623 


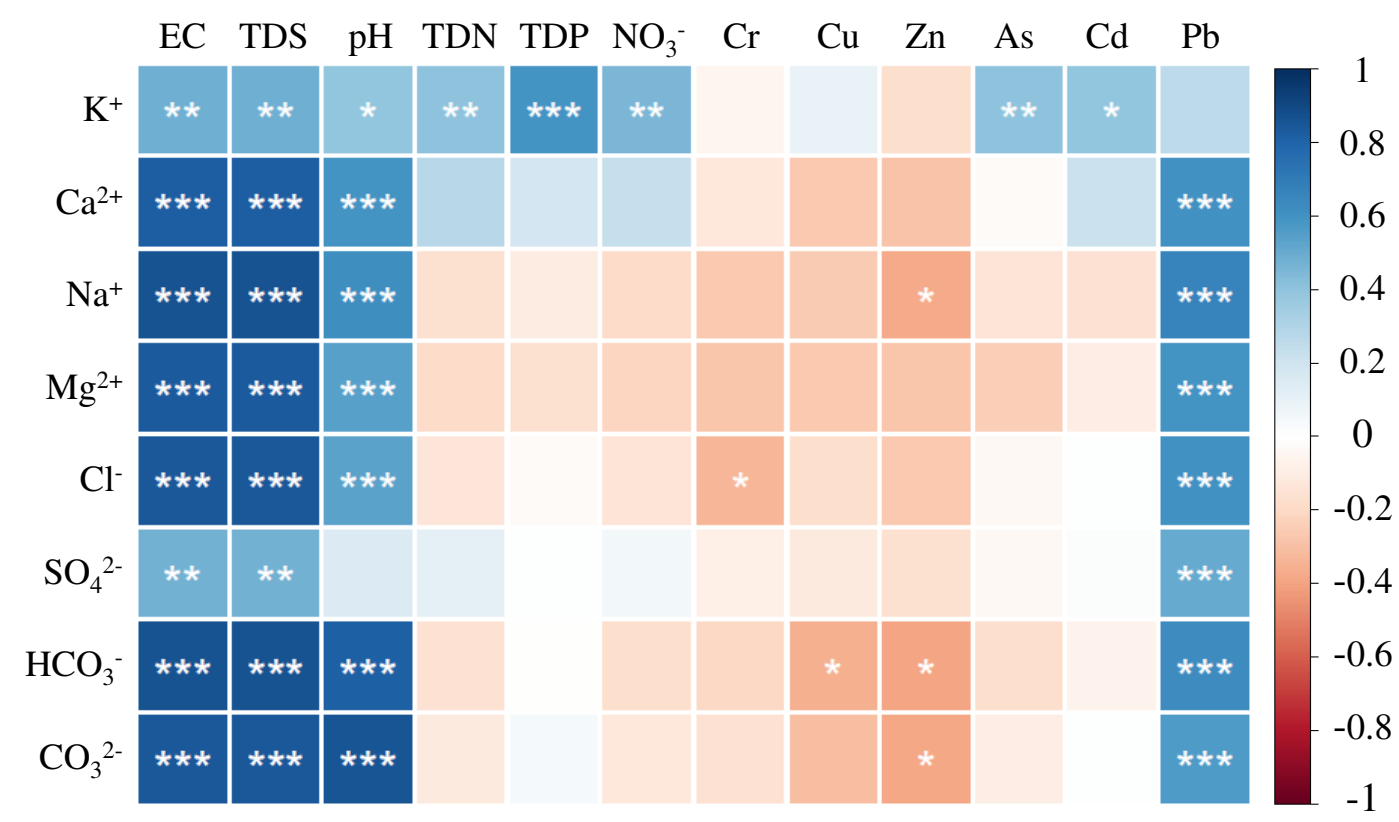

624

625 Fig. 8 Correlations between the major ions and basic water quality parameters or heavy

626 metals in groundwater. $* \mathrm{p}<0.05, * * \mathrm{p}<0.01$, and $* * * \mathrm{p}<0.001$. 


\section{Supplementary Files}

This is a list of supplementary files associated with this preprint. Click to download.

- Supplementarymaterials.docx 